\title{
Absolute Isotopic Abundance Ratios and the Atomic Weight of a Reference Sample of Silicon
}

\author{
I. L. Barnes, L. J. Moore, L. A. Machlan, \\ T. J. Murphy, and W. R. Shields* \\ Institute for Materials Research, National Bureau of Standards, Washington, D.C. 20234
}

(August 27, 1975)

\begin{abstract}
Absolute values have been obtained for the isotopic abundance ratios of a reference sample of silicon using electron impact mass spectrometry. Samples of known isotopic composition prepared from nearly isotopically pure separated silicon isotopes were used to calibrate the mass spectrometers. The resulting absolute ${ }^{28} \mathrm{Si} /{ }^{30} \mathrm{Si}$ ratio $=29.74320 \pm 0.00747$ and the ${ }^{29} \mathrm{Si} /{ }^{30} \mathrm{Si}$ ratio $=1.50598 \pm 0.00086$ which yield atom percents of ${ }^{28} \mathrm{Si}=92.22933 \pm 0.00155,{ }^{29} \mathrm{Si}=4.66982 \pm 0.00124$ and ${ }^{30} \mathrm{Si}=3.10085 \pm$ 0.00074 . The atomic weight calculated from this isotopic composition is $28.085526 \cdot 0.000056$. The indicated uncertainties are overall limits of error based on 95 percent confidence limits for the means and allowances for the effects of known sources of possible systematic error. A study of natural ${ }^{28} \mathrm{Si} /{ }^{30} \mathrm{Si}$ ratio variations reported in the literature extends the estimated uncertainty in the atomic weight of natural silicon to \pm 0.00039 .
\end{abstract}

Key words: Absolute ratios; atomic weight; isotopic abundance; silicon.

*Present address: Teledyne Isotopes. Timonium. Maryland 21200.

\section{Introduction}

The Analytical Spectrometry Section of the National Bureau of Standards is conducting a long term program of absolute isotopic abundance ratios and atomic weight determinations using thermal ionization mass spectrometry. Previous elements studied include silver [1], ${ }^{1}$ chlorine [2], copper [3], bromine [4], chromium [5], magnesium [6], lead [7], boron [8], rubidium [9], rhenium [10], and potassium [11]. This present work extends the study to silicon and demonstrates an expansion of the technique to include electron impact mass spectrometry.

Interest in the atomic weight of silicon was stimulated by the long-term project of the NBS Institute for Basic Standards to replace the kilogram as a standard of mass. Mass is the remaining triumvir of the $m-k-s$ measurement system whose definition is expressed in terms of an artifact physical unit - the platinum-iridium $1-\mathrm{kg}$ mass that resides in Paris. The meter and second have been redefined as multiples of measurable natural phenomena.

As a milestone in achieving this goal, a high purity silicon crystal of high lattice perfection was selected

\footnotetext{
1 Figures in brackets indicate the literature references at the end of this paper.
}

as a candidate for the measurement of its unit cell dimensions, density and atomic weight, with desired measurement uncertainties for each of these at the parts-per-million level or less. Since silicon in nature consists of a mixture of three stable and nonradioactive isotopes $\left({ }^{28} \mathrm{Si},{ }^{29} \mathrm{Si},{ }^{30} \mathrm{Si}\right)$, the uncertainty of the relative proportions of these masses immediately became the limiting error in the precise characterization of the silicon crystal.

As a secondary objective, the atomic weight of silicon could also be combined with the crystal parameter measurements by the IBS to permit a new and direct redetermination of Avogadro's Constant [12].

Finally, also unanswered was the question of whether the atomic weight of the silicon crystal had been distorted during the zone refining purification process.

To achieve these objectives a project was begun to determine the absolute silicon isotope abundance ratios and, hence, the atomic weight of a reference sample of silicon, with an intermediate goal of $\leqslant 10$ parts-per-million ( $\mathrm{ppm})$ uncertainty in the atomic weight.

To obtain absolute isotopic ratios from the observed or relative measurements made on a mass spectrometer it is necessary to calibrate the instrument using samples of accurately known isotopic ratios of the element 
under study. These synthetic isotopic standards, prepared from chemically pure and very nearly isotopically pure separated isotope. provide a bias or fractionation correction (calculated isotope ratio-observed isotope ratio) which when applied to the observed isotope ratio of the reference sample being calibrated allow an absolute ratio to be calculated for this sample. The atomic weight can then be calculated from the absolute isotopic abundances and the atomic masses reported by Wapstra and Gove [13].

Prior to 1948 the accepted atomic weight of silicon was 28.06 based on the work of Baxter et al. [14] measuring the ratios $\mathrm{SiCl}_{4}: 4 \mathrm{Ag}$ and $\mathrm{SiBr}_{4}: 4 \mathrm{Ag}$. Based on the isotopic ratios measured by White and Cameron $[15]$ and others the value $28.086 \pm 0.001$ was accepted [16] but the error limits were expanded to \pm 0.003 [17] based on the report of the variations of silicon isotopes by Allenby [18].

\section{Experimental Procedure}

\subsection{Mass Spectrometry}

Isotope ratio measurements were made on a $60^{\circ}$ extended flight path $15 \mathrm{~cm}(6$ inch) mass spectrometer. The mass spectrometer was equipped with a " $Z$ " focusing thin lens source [19] (see below). The collector was a deep bucket Faraday Cage type equipped with a 50 percent transmission grid shadowing a series of electron suppression grids [20]. The measuring circuit consisted of two state-of-the-art vibrating reed electrometers with provisions for automatic range switching. The output of the measuring system was fed into both an expanded scale recorder [21] and a digital system consisting of a voltage to frequency converter and a precision scaler-timer. In general both systems were used redundantly. The digital system and the range switching systems were under computer control.

Mass measurements were made by magnetic field switching. The magnetic field was controlled and changed with the use of a gaussmeter-controller. Source and collector slits were arranged so that complete resolution of each of the masses of interest was obtained.

The electron impact source used was similar to the thermal emission source normally used in our laboratory except that the shield was replaced with an electron impact section consisting of a tungsten filament, impact chamber or "cage" and an electron trap. The trap plate was provided with an external electrical circuit so that it could be continuously heated to about $300{ }^{\circ} \mathrm{C}$ which reduced the background to negligible levels.

The sample gas was admitted to the impact region through a short section of Teflon " tubing from a leak of the type described by Shields [22].

${ }^{2}$ Certain commercial products are identified in order to adequately specify the experimental procedure. In no case does such identification imply recommendation or endorse ment by the National Bureau of Standards, nor does it imply that the products identified are necessarily the best available for the purpose.
The operating parameters of the source were as follows:

$\begin{array}{lrl}\text { Electron energy } & 50 & \mathrm{eV} \\ \text { Accelerating potential } & 4780 & \mathrm{~V} \\ \text { Emission current } & 85 & \mu \mathrm{A} \\ \text { Trap current } & 80 & \mu \mathrm{A} \\ \text { Filament current } & 3.0 & \mathrm{~A}\end{array}$

The various samples of reference materials and of separated isotopes prepared as described below were processed for analysis using essentially the system described by Reynolds and Verhoogen [23] in which solid barium fluosilicate $\left(\mathrm{BaSiF}_{6}\right)$ was heated to produce $\mathrm{BaF}_{2}$ and gaseous $\mathrm{SiF}_{4}$. The silicon tetrafluoride was collected and introduced into the mass spectrometer to become the source of the $\mathrm{SiF}_{3}^{+}$ions which were measured.

The vacuum system used for the preparation of the $\mathrm{SiF}_{4}$ was constructed of nickel and copper tubing instead of the glass system used by Reynolds and Verhoogen since it was believed that the glass itself might be the source of small amounts of water which might lead to the formation of $\mathrm{SiF}_{2} \mathrm{O}^{+}, \mathrm{SiF}_{2} \mathrm{HO}^{+}$and $\mathrm{SiF}_{2} \mathrm{H}_{2} \mathrm{O}^{+}$ions as noted by them (see below).

The sample was placed in a $3 / 4$-inch nickel tube approximately $30 \mathrm{~cm}$ long which was attached to a vacuum line through a "Dalton" fitting with an aluminum gasket. The vacuum line constructed of $5 / 8$-inch copper tubing contained a U-tube trap which was cooled with a mixture of dry ice-ethanol during processing of the sample. The silicon tetrafluoride gas was collected in a nickel sample tube cooled with liquid nitrogen.

In a typical sample preparation cycle a new sample tube was placed on the vacuum system evacuated to a pressure of $<10^{-5} \mathrm{~Pa}\left(10^{-7}\right.$ torr), the trap cooled, a tube furnace placed around the sample container and the tube baked at a temperature of $700{ }^{\circ} \mathrm{C}$ for $1 \mathrm{hr}$. The furnace was then turned off and the tube was allowed to cool to room temperature. The tube was removed from the system and $100 \mathrm{mg}$ of the $\mathrm{BaSiF}_{6}$ was added. The tube was reattached to the system and evacuated with a sample collecting tube attached to the system. When a pressure of $<10^{-5} \mathrm{~Pa}\left(10^{-7}\right.$ torr) was reached the U-tube trap was cooled and liquid nitorgen placed on the sample collecting tube. At this point the vacuum system was valved off, the furnace turned on and the sample heated to $410{ }^{\circ} \mathrm{C}\left( \pm 5{ }^{\circ} \mathrm{C}\right.$ measured with a calibrated chromel-alumel thermocouple) at a rate of approximately $7 \% \mathrm{~min}$. Previous experiments had shown that at a temperature of $400{ }^{\circ} \mathrm{C}$ the sample had completely decomposed and the $\mathrm{SiF}_{4}$ produced was quantitatively removed and collected. This was substantially in agreement with the results of Reynolds and Verhoogen. After a period of $10 \mathrm{~min}$ at $410{ }^{\circ} \mathrm{C}$ the furnace was turned off and allowed to cool to below $200{ }^{\circ} \mathrm{C}$ after which the main vacuum system valve was opened and the system pumped out for 15 min to remove any other gases in the system not held at liquid nitrogen temperature in the sample collecting tube. The sample 
collecting tube valve was closed, the liquid nitrogen removed and the tube was allowed to warm to room temperature after which it was connected to the mass spectrometer inlet manifold.

During subsequent analyses of the gas the sample collection tube was always cooled in a dry ice-ethanol bath to ensure that no water vapor would enter the spectrometer. Examination of the mass region of interest and for seven or eight mass units both above and below showed no sign of interfering peaks.

One further precaution was observed during sample preparation to ensure that no inadvertant isotopic contamination could occur. A number of sample tubes, sample collection tubes, and vacuum manifold U-traps were constructed, marked and tagged. A separate set was used for the preparation of each different sample.

\subsection{Purification of Separated Silicon Isotopes}

The final goal of achieving stoichiometric assays of the enriched isotopes at the 0.01 percent precision and accuracy level is strongly dependent on the chemical purity of each isotope. The enrichment of the ${ }^{28} \mathrm{Si}$ and ${ }^{30} \mathrm{Si}$ isotopes was done by electromagnetic separation at Oak Ridge National Laboratory (Union Carbide Nuclear Company). Collection of each high energy separated Si ion beam was effected with a graphite faraday cup. Thus the removal of the separated isotope from the graphite cup resulted in a material, as received at NBS, that was a mixture of $\mathrm{SiO}_{2}, \mathrm{SiC}_{\text {and }}$ graphite. The silicon 28 was designated sample 900390 and consisted of $4.452 \mathrm{~g}$ of mixed $\mathrm{SiO}^{2}$ and $\mathrm{SiC}$ along with some graphite from the collector. The silicon 30 was designated sample 900490 and consisted of $200 \mathrm{mg}$ of the same type mixture.

The ${ }^{28} \mathrm{Si}$ separated isotope sample was transferred to a $100 \mathrm{ml}$ FEP-Teflon beaker and the silicon dioxide along with any silicon metal present in the material was dissolved by adding $16 \mathrm{~g}$ of 50 percent sodium hydroxide solution and diluting to $50 \mathrm{ml}$. The solution was digested overnight on a hot plate at about $80{ }^{\circ} \mathrm{C}$ and filtered through a close textured filter paper. The insoluble residue and filter paper were washed with water, transferred to a platinum crucible and the paper and residue were ignited over a Meeker burner. About 25 percent $(1 \mathrm{~g})$ of the original material remained and was assumed to be silicon carbide.

The filtrate was split into two equal portions and each portion was diluted to $500 \mathrm{ml}$ in Teflon beakers. Each portion was passed through a strongly acidic cation exchange column to remove sodium and other cations. The columns were constructed from polystyrene and were approximately $33 \mathrm{~cm}$ long and of $2.5 \mathrm{~cm}$ inside diameter. They were filled to a height of $25 \mathrm{~cm}$ with Bio-Rad AG50 ×8, 100-200 mesh, cation exchange resin. The eluates were caught in Teflon beakers. Each column was washed with about $150 \mathrm{ml}$ of water to completely remove the silicic acid, $\mathrm{H}_{2}{ }^{28} \mathrm{SiO}_{3}$, from the column. The eluates and washings were then evaporated to dryness on a hot plate and the resulting hydrated silica, ${ }^{28} \mathrm{SiO}_{2} \cdot x \mathrm{H}_{2} \mathrm{O}$, was transferred to a 50 -ml platinum crucible.
The $1 \mathrm{~g}$ of ${ }^{28} \mathrm{SiC}$ insoluble residue resulting from the filtration of the sodium hydroxide solution was decomposed by sodium carbonate fusion. About $5 \mathrm{~g}$ of sodium carbonate was added to a $20-\mathrm{ml}$ platinum crucible and about $50 \mathrm{mg}$ of the ${ }^{28} \mathrm{SiC}$ was added. The crucible was covered with a platinum cover and heated over a Meeker burner at moderate heat to fuse the $\mathrm{Na}_{2} \mathrm{CO}_{3}$ and react with the ${ }^{28} \mathrm{SiC}$. After a few minutes the heat was raised to the full Meeker burner temperature for about $5 \mathrm{~min}$. The crucible and contents were then cooled, the cover removed, a second $50 \mathrm{mg}$ portion of ${ }^{2}{ }^{8} \mathrm{SiC}$ added, and the $\mathrm{Na}_{2} \mathrm{CO}_{3}$ fusion repeated. This procedure was repeated until the entire sample of ${ }^{28} \mathrm{SiC}$ had been added and fused. One gram of $\mathrm{Na}_{2} \mathrm{CO}_{3}$ was added to the original platinum crucible and fused to react with any remaining ${ }^{28} \mathrm{SiC}$. The sodium carbonate melts were dissolved in about $400 \mathrm{ml}$ of $\mathrm{H}_{2} \mathrm{O}$ in a $500-\mathrm{ml}$ Teflon beaker. The solution was titrated with $(1+4) \mathrm{HCl}$ to $\mathrm{PH} 5-6$ (as determined by $\mathrm{pH}$ indicating paper), the $\mathrm{CO}_{2}$ expelled by rapid stirring, and the solution was made alkaline with dilute sodium hydroxide to about $\mathrm{pH}$ 9. The solution was then passed through a cation exchange column as described for the sodium hydroxide solution of the soluble silica. The eluate was caught in a Teflon beaker, evaporated to dryness and the resulting hydrated silica was transferred to the platinum crucible that contained the previously separated silica. The crucible was then covered with a platinum cover and ignited in an electric muffle furnace at $800{ }^{\circ} \mathrm{C}$ for several hours. The total recovered ${ }^{28} \mathrm{SiO}_{2}$ weighed $4.185 \mathrm{~g}$ equivalent to $1.952 \mathrm{~g}$ of ${ }^{28} \mathrm{Si}$.

The ${ }^{30} \mathrm{Si}$ separated isotope mixture was taken into solution in a manner similar to the ${ }^{28} \mathrm{Si}$ procedure except on a reduced scale because of the smaller sample size. The total sample was transferred to a $100-\mathrm{ml}$ FEP-Teflon beaker and the silicon dioxide and silicon metal were dissolved by adding $2 \mathrm{~g}$ of 50 percent sodium hydroxide and diluting to $50 \mathrm{ml}$. After overnight digestion on a hot plate at about $80^{\circ} \mathrm{C}$, the solution was filtered through a close textured filter paper. The insoluble residue and filter paper were washed with $\mathrm{H}_{2} \mathrm{O}$, transferred to a platinum crucible, and ignited over a Meeker burner. About 50 percent $(97 \mathrm{mg})$ of the original material remained and was assumed to be ${ }^{30} \mathrm{SiC}$.

The filtrate containing the sodium hydroxide soluble (silicon was passed through a strongly acidic cation exchange column constructed from polypropylene and containing about $35 \mathrm{ml}$ of Bio-Rad AG50 $\times 8$ resin, 100-200 mesh. The column was washed with $70 \mathrm{ml}$ of water to completely remove the silicic acid, $\mathrm{H}_{2}{ }^{30} \mathrm{SiO}_{3}$, from the column and the eluate and washings were evaporated to dryness. The residue was transferred to a $10-\mathrm{ml}$ platinum crucible and ignited to ${ }^{30} \mathrm{SiO}_{2}$ over a Meeker burner.

The silicon carbide insoluble residue resulting from the filtration of the sodium hydroxide solution was decomposed by sodium carbonate fusion in the same manner as the ${ }^{28} \mathrm{SiC}$ except that only $1 \mathrm{~g}$ of $\mathrm{Na}_{2} \mathrm{CO}_{3}$ was used. Any ${ }^{30} \mathrm{SiC}$ remaining in the original platinum crucible was dissolved by fusion with $0.2 \mathrm{~g} \mathrm{Na} \mathrm{CO}_{3}$. The sodium carbonate melts were dissolved in about 
$100 \mathrm{ml}$ of $\mathrm{H}_{2} \mathrm{O}$ in a Teflon beaker. The solution was titrated with $(1+4) \mathrm{HCl}$ to $\mathrm{pH} 5-6$ (as determined by $\mathrm{pH}$ indicating paper), the $\mathrm{CO}_{2}$ was expelled by rapid stirring, and the solution was made alkaline with dilute sodium hydroxide solution to about $\mathrm{pH} 9$. This solution was then passed through the same cation column as the sodium hydroxide fraction and the column was washed with about $70 \mathrm{ml}$ of $\mathrm{H}_{2} \mathrm{O}$. The eluate and washings were caught in a Teflon beaker, evaporated to dryness, and the residue was transferred to the platinum crucible that contained the previously separated ${ }^{30} \mathrm{SiO}_{2}$. The crucible was then covered with a platinum cover and ignited to an electric muffle furnace at $1000{ }^{\circ} \mathrm{C}$ for $1 / 2 \mathrm{~h}$. The ${ }^{30} \mathrm{SiO}_{2}$ recovered weighed $0.1814 \mathrm{~g}$ equivalent to $87.8 \mathrm{mg}$ of ${ }^{30} \mathrm{Si}$.

Throughout these procedures, the utmost care was used to prevent contamination of the isotopes with natural silicon. All of the beakers, ion-exchange columns ion-exchange resins and filter papers were cleaned with dilute high-purity hydrofluoric acid before use. All of the chemical reagents were selected for low silicon content. For example, the total system blank for the purification of the ${ }^{30} \mathrm{Si}$ isotope amounted to $4 \mu \mathrm{g}$ of natural silicon or about 0.0003 percent of the ${ }^{30} \mathrm{Si}$.

\subsection{Preparation and Analysis of the Separated Isotope Solutions}

The $4.18 \mathrm{~g}$ of purified ${ }^{28} \mathrm{SiO}_{2}$ was transferred to a 250-ml Teflon beaker and dissolved in a mixture of $130 \mathrm{ml}$ of water and $30 \mathrm{ml}$ of high-purity 48 percent hydrofluoric acid at room temperature. The solution was transferred to a tared $500-\mathrm{ml}$ Teflon bottle and diluted to approximately $300 \mathrm{~g}$ with water containing $30 \mathrm{ml}$ of concentrated hydrofluoric acid to give a solution containing approximately $0.18 \mathrm{mmol} / \mathrm{g}_{2}$ of $\mathrm{H}_{2}{ }^{28} \mathrm{SiF}_{6}$ in $3 \mathrm{~N}$ hydrofluoric acid. This solution was designated "Si-28".

The $0.181 \mathrm{~g}$ of purified ${ }^{30} \mathrm{SiO}_{2}$ was transferred to a 100-ml Teflon beaker and dissolved in a mixture of $35 \mathrm{ml}$ of water and $7 \mathrm{ml}$ of 48 percent hydrofluoric acid at room temperature. The solution was transferred to a $125 \mathrm{ml}$ tared FEP-Teflon bottle and diluted with water to approximately $55 \mathrm{~g}$ to give a solution approximately $0.05 \mathrm{mmol} / \mathrm{g}$ of $\mathrm{H}_{2}{ }^{30} \mathrm{SiF}_{6}$ in $3 \mathrm{~N}$ hydrofluoric acid. The solution was designated "Si-30".

Samples of the "Si-28" and "Si-30" were analyzed for impurity elements by isotope-dilution spark source mass spectrometry. Samples equivalent to about $5 \mathrm{mg}$ of silicon were spiked with $10^{-7} \mathrm{~g}$ of ${ }^{109} \mathrm{Ag},{ }^{137} \mathrm{Ba},{ }^{44} \mathrm{Ca}$, ${ }^{111} \mathrm{Cd},{ }^{53} \mathrm{Cr},{ }^{65} \mathrm{Cu},{ }^{4} \mathrm{Fe},{ }^{41} \mathrm{~K},{ }^{26} \mathrm{Mg},{ }^{97} \mathrm{Mo},{ }^{62} \mathrm{Ni},{ }^{206} \mathrm{~Pb}$ ${ }^{123} \mathrm{Sb},{ }^{82} \mathrm{Se},{ }^{117} \mathrm{Sn},{ }^{86} \mathrm{Sr},{ }^{125} \mathrm{Te},{ }^{203} \mathrm{Tl},{ }^{67} \mathrm{Zn}$. After the addition of $0.5 \mathrm{ml}$ of perchloric acid to each sample, the silicon matrix was volatilized as $\mathrm{SiF}_{4}$ by evaporation to a small drop of perchloric acid. The drop was transferred to a pair of gold wires, evaporated onto the wires, and the deposit was analyzed by spark source mass spectrometry .

In addition to the elements determined by isotope dilution, $\mathrm{Al}, \mathrm{As}, \mathrm{Na}$, and $\mathrm{Sb}$ were estimated by comparison to isotopes of other elements. Table 1 shows the result of these analyses. The results showed that there was no significant difference in the purity of the two isotope solutions at a level that could interfere with the assay method for silicon which was based on the gravimetric determination of $\mathrm{Cs}_{2} \mathrm{SiF}_{6}$. The principal interferences are the elements that form insoluble fluosilicates such as the alkalies and alkaline earths.

In addition to the elements reported in table 1 , tungsten was detected in the "Si-30" solution. Subsequent analysis of $\mathrm{Cs}_{2}{ }^{30} \mathrm{SiF}_{6}$ from the assay using a ${ }^{183} \mathrm{~W}$ spike showed that the tungsten concentration was negligible at less than $3 \mathrm{ppm}$.

\subsection{Assay of the Separated Isotope Solutions}

Four weighed portions each containing about $10 \mathrm{mg}$ of silicon, were withdrawn from each separated isotope solution in the following manner. A $10-\mathrm{cm}$ platinum needle was inserted through a No. 2 polyethylene stopper and used to replace the cap in the bottle. A 10 -ml polyethylene hypodermic syringe with the plunger covered with a thin sheet of Teflon was attached to the Kel-F hub of the needle and the desired amount of solution was withdrawn. The syringe was then disconnected from the hub and the tip was capped with a Kel-F cap. Any static charge that might be present on the plastic syringe was dissipated by wiping it with a damp lintless towel. The syringe and contents were weighed on a semimicrobalance to $\pm 0.02 \mathrm{mg}$. The solution was then delivered from the syringe into a 50-ml Teflon-FEP beaker and the syringe was again capped, wiped and weighed. The weight of the sample was determined from the weight of the syringe before and after delivery of the sample. Two assay samples were withdrawn from each solution before and after

TABLE 1. Analysis of silicon isotopes

\begin{tabular}{|c|c|c|}
\hline Element & $\begin{array}{c}{ }^{\prime} \mathrm{Si}-28 " \\
\mathrm{ppm}\end{array}$ & $\begin{array}{c}{ }^{*} \mathrm{Si}-30 * \\
\mathrm{ppm}\end{array}$ \\
\hline $\mathrm{A} g$ & 7 & 2 \\
\hline${ }^{a} \mathrm{Al}$ & 5 & 3 \\
\hline b) As & 3 & 2 \\
\hline $\mathrm{Ba}$ & 0.5 & 1 \\
\hline $\mathrm{Ca}$ & 5 & 3 \\
\hline $\mathrm{Cd}$ & 1 & 4 \\
\hline $\mathrm{Cr}$ & 10 & 30 \\
\hline $\mathrm{Cu}$ & 4 & 4 \\
\hline $\mathrm{Fe}$ & 18 & 26 \\
\hline $\mathrm{K}$ & 1 & 7 \\
\hline $\mathbf{M}_{\dot{v}}$ & 1 & 1 \\
\hline Mo & 3 & 20 \\
\hline${ }^{\prime} \mathrm{Na}$ & ${ }^{\mathrm{e}} 30$ & 50 \\
\hline $\mathrm{Ni}$ & 2 & 7 \\
\hline Pb & 1 & 2 \\
\hline${ }^{\mathrm{d}} \mathrm{Sb}$ & 21 & $\overline{7}$ \\
\hline $\mathrm{Se}$ & 3 & 0.2 \\
\hline Sn & 1 & 5 \\
\hline $\mathrm{Sr}$ & 0.2 & 0.3 \\
\hline $\mathrm{Te}$ & 0.5 & 1 \\
\hline $\mathrm{Tl}$ & 1 & 1 \\
\hline $\mathrm{Zn}$ & 1 & 8 \\
\hline
\end{tabular}

\footnotetext{
"Versus ${ }^{26} \mathrm{M}$

Versus ${ }^{\mathrm{N}} \mathrm{Se}$

Versus ${ }^{41} \mathrm{~K}$

"Versus ${ }^{117} \mathrm{Sn}$

e Value not significantly different from blank.
} 
withdrawing the calibration samples to ensure that no change in concentration had occurred during this time interval (about $3 \mathrm{~h}$ ).

Each weighed portion was then assayed as follows: The "Si-28" solutions were diluted to approximately $6 \mathrm{ml}$ with $1 N \mathrm{HF}$. The "Si-30" aliquots were $6 \mathrm{ml}$ so no further dilution was required. A weighed aliquot of $\mathrm{CsCl}$ solution (100 $\mathrm{mg} \mathrm{CsCl} / \mathrm{g}$ ) was added to the separated isotope assay solution in an amount to give approximately 10 percent excess of the stoichiometric amount required to yield cesium fluosilicate, $\mathrm{Cs}_{2} \mathrm{SiF}_{6}$. Twenty grams of acetone were added to the beaker, the solution was covered and stored in a plastic box with an open beaker of acetone to prevent excessive loss of acetone from the assay solution. After allowing the solution to stand at least $48 \mathrm{~h}$ (the "Si-28" solution stood for 5 days) it was filtered through a weighed $15-\mathrm{ml}$ Munroe crucible and washed with approximately $20 \mathrm{ml}$ of a 90 percent acetone/10 percent water $(\mathrm{v} / \mathrm{v})$ solution. (The filtrate and washings were transferred back to the original beaker and reserved for the determination of dissolved and untransferred silicon.) The crucible and contents were dried for $2 \mathrm{~h}$ at $110{ }^{\circ} \mathrm{C}$, allowed to cool in a desiccator, transferred to the case of a microbalance and allowed to stand for at least $1 \mathrm{~h}$. The crucible and contents were weighed to $\pm 0.002 \mathrm{mg}$. A combination blank and buoyancy correction was made by averaging three crucibles that had been used to filter blank samples carried through the procedure. The drying, cooling and weighing were repeated until constant weight was reached. The air weight of the $\mathrm{C}_{\mathrm{s}_{2}} \mathrm{SiF}_{6}$ was then determined and converted to vacuum weight using a Chemical Rubber Handbook (54th edition) value of 3.372 as the density of the salt. The micromoles of silicon present in the salt were determined using a calculated atomic weight for silicon and 1973 atomic weight values for the other two elements. The formula weights used were 407.7782 for $\mathrm{Cs}_{2}{ }^{28} \mathrm{SiF}_{6}$ and 409.7463 for $\mathrm{Cs}_{2}{ }^{30} \mathrm{SiF}_{6}$.

The filtrate from the precipitation of the cesium fluosilicate was transferred to the original beaker and about $15 \mathrm{ml}$ of water was added to insure that any untransferred salt was dissolved. The acetone was removed by evaporating the solution to approximately $15 \mathrm{ml}$.

The solution was transferred to a 100-ml FEP-Teflon beaker and $40 \mathrm{~g}$ of boric acid solution $(5 \mathrm{~g} / 100 \mathrm{ml})$ and $4 \mathrm{~g}$ of molybdic acid solution (25 $\mathrm{g}$ of ammonium molybdate tetrahydrate dissolved in $200 \mathrm{ml}$ of $\mathrm{H}_{2} \mathrm{SO}_{4}$ $(1+9)$ and diluted to $250 \mathrm{ml}$ with water) were added. After mixing, the $\mathrm{pH}$ of the solution was adjusted to 1.7-1.8 with $\mathrm{NH}_{4} \mathrm{OH}(1+1)$. After allowing the solution to stand for $10 \mathrm{~min}, 4 \mathrm{~g}$ of tartaric acid solution $(25 \mathrm{~g} / 100 \mathrm{ml})$ was added. The solution was mixed and $4 \mathrm{~g}$ of reducing solution ( $27 \mathrm{~g}$ of sodium bisulfite, $2 \mathrm{~g}$ of sodium hydroxide and $0.5 \mathrm{~g}$ of 1 -amino 2-napthol 4-sulfonic acid dissolved in $250 \mathrm{ml}$ of water and filtered through a close-textured paper) was added. The solution was transferred to a $100-\mathrm{ml}$ volumetric flask, filled to the mark with water and thoroughly mixed. The absorbancy was measured on a spectrophotometer at $650 \mathrm{~nm}$ using a 2 -cm cell with water in the reference cell. The micromoles of silicon were calculated from a curve plotted by carrying known amounts of silicon through the same procedure. The silicon found was added to the silicon from the gravimetric determination to yield the total silicon in the sample. Table 2 shows the results of these analyses.

This method of determining the concentration of silicon solutions was previously tested on solutions containing known amounts of silicon. Two solutions were prepared from high purity silicon, SRM 990. Three sets of four samples each containing from 320 to $420 \mu \mathrm{mol}$ of silicon were withdrawn from each solution and the silicon concentrations were determined as described above. Comparison of the calculated and measured concentrations showed biases of -0.017 and -0.032 percent for the two solutions. The silicon was dissolved in diluted $\mathrm{HNO}_{3}$ and $\mathrm{HF}$ and there was apparently a greater loss of $\mathrm{Si}$ as $\mathrm{SiF}_{4}$ from one solution than the other. The concentration determined for each solution was internally consistent with concentrations of $0.107778 \pm 0.000012$ and $0.106541 \pm 0.00001 \mu \mathrm{mol} / \mathrm{g}$ for 12 determinations on each solution.

Pooling the results of the "Si-28" separated isotope solutions with the results of the six sets described

TABLE 2. Concentration of silicon isotope solutions

\begin{tabular}{|c|c|c|c|c|c|c|}
\hline \multirow[b]{2}{*}{ Solution } & \multirow{2}{*}{$\begin{array}{c}\text { Sample } \\
\text { No. }\end{array}$} & \multirow[b]{2}{*}{$\begin{array}{c}\text { Weight } \\
\text { solution } g\end{array}$} & \multicolumn{2}{|c|}{ Silicon } & \multirow[b]{2}{*}{$\begin{array}{l}\text { Total } \\
\text { silicon } \\
\mu \mathrm{mol}\end{array}$} & \multirow[b]{2}{*}{$\begin{array}{c}\text { Conc. } \\
\text { solution } \\
\mu \mathrm{mol} \mathrm{Si} / \mathrm{g}\end{array}$} \\
\hline & & & $\begin{array}{c}\text { From ppt } \\
\mu \mathrm{mol}\end{array}$ & $\begin{array}{c}\text { From sol } \\
\mu \mathrm{mol}\end{array}$ & & \\
\hline "Si-28" & $\begin{array}{l}1 \\
2 \\
3 \\
4\end{array}$ & $\begin{array}{l}2.20065 \\
2.08974 \\
2.03935 \\
2.09052\end{array}$ & $\begin{array}{l}390.482 \\
370.552 \\
361.606 \\
370.763\end{array}$ & $\begin{array}{r}0.182 \\
.332 \\
.379 \\
.283\end{array}$ & $\begin{array}{l}390.664 \\
370.884 \\
361.985 \\
371.046\end{array}$ & $\begin{array}{l}177.522 \\
177.479 \\
177.500 \\
177.490 \\
177.498\end{array}$ \\
\hline Average & $\begin{array}{l}1 \\
2 \\
3 \\
4\end{array}$ & $\begin{array}{l}6.64491 \\
6.27097 \\
6.62758 \\
6.63155\end{array}$ & $\begin{array}{l}355.205 \\
335.154 \\
354.344 \\
354.524\end{array}$ & $\begin{array}{r}0.374 \\
.387 \\
.242 \\
.317\end{array}$ & $\begin{array}{l}355.579 \\
335.541 \\
354.586 \\
354.841\end{array}$ & $\begin{array}{l}53.5115 \\
53.5070 \\
53.5016 \\
53.5080 \\
53.5070\end{array}$ \\
\hline
\end{tabular}


above yields a value of $0.0000126 \mu \mathrm{mol} / \mathrm{g}$ for the standard deviation of an individual measurement.

\subsection{Isotopic Analysis of Separated Isotopes}

The quantities of "Si-28" and "Si-30" were transferred as the barium compound and decomposed to $\mathrm{SiF}_{4}$ as described above. Because of the very large ratios these compounds were measured using a $30 \mathrm{~cm}$ radius mass spectrometer which was otherwise identical to the $15 \mathrm{~cm}$ radius used for the remaining measurements. The results of these measurements are given in table 3 .

TABLE 3. Measurements of the separated isotopes

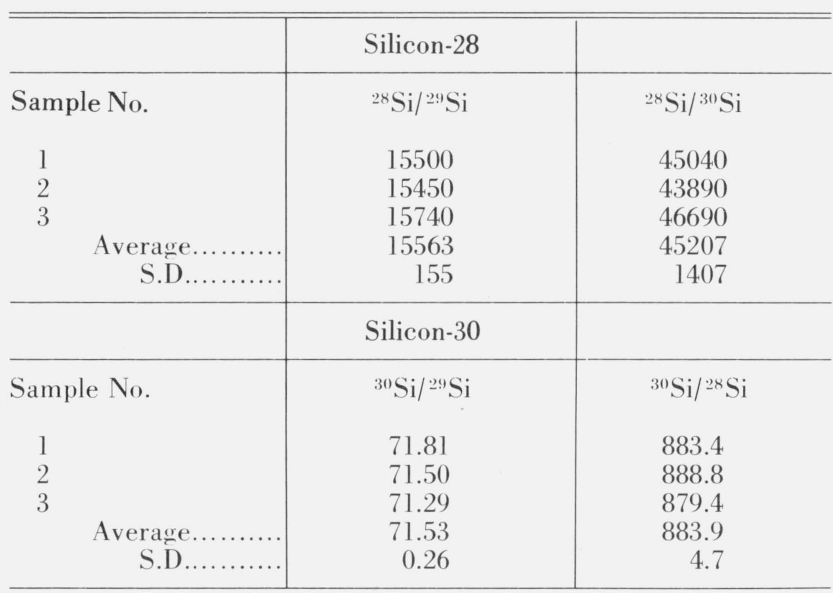

\subsection{Preparation of Calibration Samples}

Three calibration samples were prepared by mixing weighed portions of the "Si-28" and "Si-30" solutions. One mixture was within 0.25 percent of the observed natural ${ }^{28} \mathrm{Si} /{ }^{30} \mathrm{Si}$ ratio of 29.7 and the other two mixtures bracketed the natural ratio by 2 percent. The portions were withdrawn from the bottles and weighed in the manner previously described for the assay of the solution. To ensure that there had been no change in concentration of an isotope solution with time, the portions for the calibration samples were withdrawn from the bottles between the samples taken for assay.

Table 4 shows the concentration of the calibration samples calculated from the isotopic analysis of the separated isotopes and the micromoles of silicon from each separated isotope solution as determined from the assay and weight of solution taken.

Each calibration sample was thoroughly mixed and a weighed aliquot of $\mathrm{BaCl}_{2}$ solution $(100 \mathrm{mg} \mathrm{BaCl} / 2 / \mathrm{g})$ was added in an amount to give a 1 percent excess of the stoichiometric amount required to yield barium fluosilicate, $\mathrm{BaSiF}_{6}$. The solution was evaporated to dryness at low heat $\left(\sim 80{ }^{\circ} \mathrm{C}\right)$ on a hot plate. Each sample was evaporated separately to avoid any possibility of cross-contamination.

\subsection{Measurement of the Relative Ratios of the Reference Material}

To determine the relative, or uncalibrated, isotopic abundances of the reference material, SRM 990 samples were prepared as described above and the isotopic ratios measured. To ensure that no instrumental memory effects were observed a careful background scan of the measured region was made before the introduction of each sample. No sample was examined if the mass 85 position showed a detectable signal of more than $3 \times 10^{-15} \mathrm{~A}$. Sufficient sample was introduced to give a total silicon beam intensity of $3 \times 10^{-11} \mathrm{~A}$ and the ratios measured in a pattern of $10{ }^{28} \mathrm{Si} /{ }^{29} \mathrm{Si}$ ratio measurements, $20{ }^{30} \mathrm{Si} /{ }^{29} \mathrm{Si}$ ratios and $10{ }^{28} \mathrm{Si} /{ }^{29} \mathrm{Si}$ ratios. Additional sample was then introduced to give a signal intensity of $7 \times 10^{-11} \mathrm{~A}$ and the ratio measurement repeated. After this the pattern was repeated at signal intensities of $3 \times 10^{-10} \mathrm{~A}$ and $7 \times 10^{-11} \mathrm{~A}$. In no case did the ratios show a change outside of experimental error for each of the four different runs on each sample. The results of the relative measurements of the reference samples are shown in table 5 .

\subsection{Comparison of the Isotopic Ratios of the Calibra- tion Mixes and the Reference Sample}

In the measurements of the isotopic ratios of gases such as silicon tetrafluoride using electron impact ionization sources the problem of memory is nearly always encountered. Although large and efficient vacuum systems help alleviate the problem the gas molecules adsorb on components of the source and are released with the introduction of subsequent samples causing an unpredictable alteration of the isotopic composition of the sample. To eliminate these effects the so-called "constant" background or interpolative

TABLE 4. Composition of silicon calibration samples

\begin{tabular}{|c|c|c|c|c|c}
\hline \hline $\begin{array}{c}\text { Sample } \\
\text { No. }\end{array}$ & $\begin{array}{c}\text { Isotope } \\
\text { solution }\end{array}$ & $\begin{array}{c}\text { Weight } \\
\text { solution g }\end{array}$ & $\begin{array}{c}{ }^{28} \mathrm{Si} \\
\mu \mathrm{mol}\end{array}$ & $\begin{array}{c}{ }^{30} \mathrm{Si} \\
\mu \mathrm{mol}\end{array}$ & $\begin{array}{c}\text { Isotope ratio } \\
{ }^{28} \mathrm{Si} /{ }^{30} \mathrm{Si}\end{array}$ \\
\hline 1 & "Si-28", & 9.41413 & 1.6708450 & 0.0000369 & 30.389838 \\
& "Si-30" & 1.04286 & 0.0007393 & .0549688 & \\
2 & "Si-28" & 9.47683 & 1.6819732 & 0.0000372 & 29.149102 \\
& "Si-30" & 1.09454 & 0.0008074 & .0576929 & \\
3 & "Si-28" & 9.16645 & 1.6268861 & 0.0000360 & 29.815019 \\
& "Si-30" & 1.03502 & 0.0007635 & .0545556 & \\
\hline
\end{tabular}


TABLE 5. Determination of relative ratios of reference sample (SRM 990)

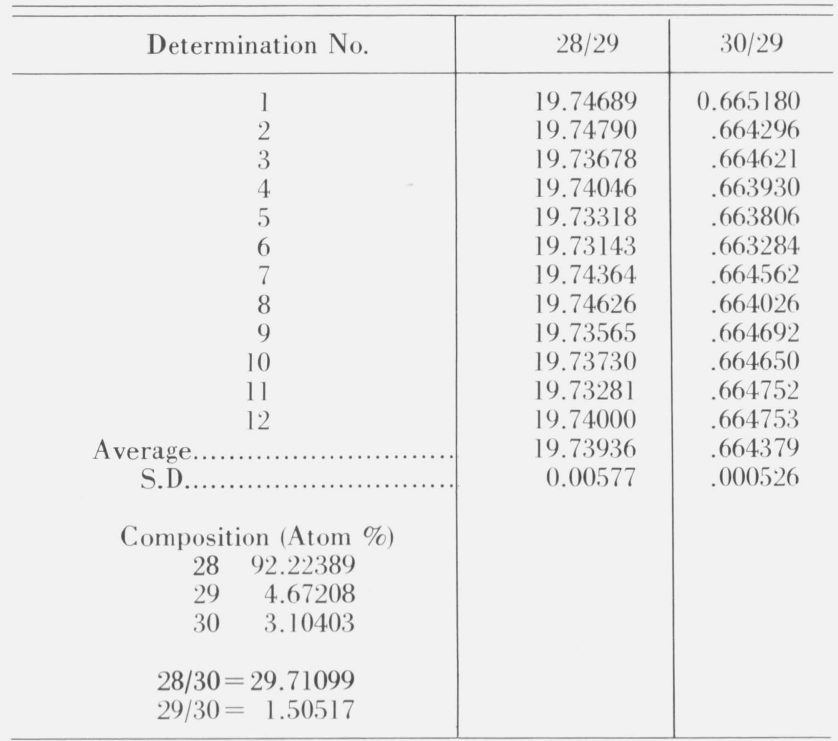

method was chosen for these measurements. The interpolative method which has been in use by the nuclear fuels industry for many years has been described in detail by Smith et al. [24] and by Rodden [25]. It consists essentially in the analysis of accurately known standards and samples in a prescribed and carefully timed pattern which permits the calculation of the precise ratio difference between samples and standards regardless of the actual isotopic ratios measured. The samples may be given accurate values through the differences measured and the known values of the standards. In this case two of the prepared synthetic mixes (A and B) were chosen with compositions slightly above and below the composition of the standard. The three samples were prepared in separate sample containers to contain exactly the same quantity of gas (within \pm 0.5 percent) and the three containers were attached to the mass spectrometer and were analyzed in the following manner. Sample A was introduced into the instrument to give a total silicon ion beam of $3 \times 10^{-11} \mathrm{~A}$. The ion beam was allowed to stabilize for exactly 2 min (all times given were controlled to $\pm 1 \mathrm{~s}$ ) after which 10 ratio measurements were made. The pump on the sample manifold was then opened and the system allowed to evacuate for 5 min after which the sample $\mathrm{X}$ was introduced as above. These measurements were repeated in the order $A-X-B-B-X-A-A-X$. . . until a minimum of $10 A-X-B-B-X-A$ cycles were completed. From each cycle a ratio of differences may be calculated as

$$
R_{D}=\frac{R_{X}-R_{A}}{R_{B}-R_{A}}
$$

where $R_{X}=$ average reading for sample entries

$R_{A}=$ average reading for low standard entries

$R_{B}=$ average reading for high standard entries and the standard related to the known values for the standards through

$$
K_{X}=R_{D}\left(K_{B}-K_{A}\right)+K_{A} .
$$

It is also possible to correct for a small amount of residual bias by use of an end point measurement. For this the standards are substituted for the unknown sample in a sequence $A-A-B-B-B-B-A-A$ and the reverse from which the end point bias may be calculated as:

$$
\begin{aligned}
R_{D A} & =\frac{R_{X A}-R_{A}}{R_{B}-R_{A}} \\
R_{D B} & =\frac{R_{X B}-R_{A}}{R_{B}-R_{A}} .
\end{aligned}
$$

If no bias exists $R_{D A}$ will be equal to zero and $R_{D B}$ equal to 1 . Normally this is not the case and the ratio of differences, $R_{D}$ is corrected as:

$$
R_{D(\text { corrected })}=\frac{R_{D}-\bar{R}_{D A}}{\bar{R}_{D B}-\bar{R}_{D A}}
$$

The value of $K_{X}$, the true isotopic ratio of the sample corrected for residual bias may then be calculated from the formula given for $K_{X}$ above. When this value of the true ${ }^{28} \mathrm{Si} /{ }^{30} \mathrm{Si}$ ratio is obtained a correction factor for the filament bias may be calculated using that and the observed ratio. This may be used to correct all other measured values to a "true" scale.

In addition to the above sequence another synthetic $\operatorname{mix}(C)$ had been prepared with isotopic ratios nearly identical to the reference material. This sample could be directly compared using the same timing program as given above in a $C-X-C-X$. . . sequence. The values of $X$, the true ${ }^{28} \mathrm{Si} /{ }^{30} \mathrm{Si}$ ratio in the reference and the correction factor obtained are shown in table 6 .

As a test of the validity of the above system this third mix $C$ was substituted for the reference material $X$, in a $A-C-B-B-C-A-A-\ldots$ sequence. The value for the ${ }^{28} \mathrm{Si} /{ }^{30} \mathrm{Si}$ ratio calculated from this measurement agreed with that known from the chemical preparation to within 0.001 percent.

TABLE 6. Summary of filament correction factor calculation

1. From comparison of mixes 2, 4 and SRM 990

$\begin{aligned} R_{I / \text { corrected })} & =0.48115 \\ \text { S.D } & =0.00428 \\ \text { True }\left({ }^{28} \mathrm{Si} \beta^{30} \mathrm{Si}\right)_{990} & =29.74608\end{aligned}$

2. From comparison of mix 5 and SRM 990

$$
\begin{aligned}
& \text { Ratio } \frac{\left({ }^{28} \mathrm{Si} /{ }^{30} \mathrm{Si}\right)_{990}}{\left({ }^{2} \mathrm{Si} /{ }^{30} \mathrm{Si}\right)_{5}}=1.002512 \\
& \text { S.D. }=0.000260 \\
& \text { True }\left({ }^{28} \mathrm{Si} /{ }^{30} \mathrm{Si}\right)_{990}=29.74031
\end{aligned}
$$

3. Average true value $=29.74320$

4. Correction factor $=\frac{29.74320}{29.71099}=1.001084$

5. Correction factor/mass unit $=1.000542$

6. True $\left({ }^{29} \mathrm{Si} /{ }^{30} \mathrm{Si}\right)_{990}=1.50598$ 


\section{Results and Discussion Calculation of Reference Sample Atomic Weight}

Using the corrected or true values for the isotopic ratios determined for the reference sample and the values of the nuclidic masses given by Wapstra and Gove [12] the atomic weight of this reference sample may be calculated. The summary of the calculations are shown in table 7 .

As mentioned above Allenby reported a variation in the ${ }^{28} \mathrm{Si} /{ }^{30} \mathrm{Si}$ ratios of 1.4 percent within the samples he analyzed. Reynolds and Verhoogen however, found only a maximum variation of 0.3 percent in materials very similar to those analyzed by Allenby. In an attempt to resolve this discrepancy Tilles [26] analyzed a large variety of samples including a number of both biological and meteoric origin. His results agreed very well with those of Reynolds and Verhoogen but extended the maximum range slightly to 0.53 percent.
Tilles suggested that laboratory fractionation in the sample preparation system used by Allenby may have been the cause of the larger variation noted by him. In view of the excellent agreement between the results of Tilles and Reynolds and Verhoogen and the much larger variety of samples analyzed it seems that a maximum variation in nature of 0.5 percent is most probable.

The authors are indebted to P. J. Paulsen who performed the spark source mass spectrometric analysis of the reference material and of the separated isotopes and to Hsien $\mathrm{H}$. $\mathrm{Ku}$ who provided the statistical analysis of the experimental data but also studied the experiment and provided helpful guidance.

The authors also acknowledge the help of the Division of Research US AEC (now ERDA) and the personnel of the Office of Isotope Sales, ORNL, for the use of the separated isotopes.

TABLE 7. Summary calculations of atomic weight of a silicon reference sample

\begin{tabular}{|c|c|c|c|c|c|}
\hline \multirow[b]{2}{*}{ Value } & \multicolumn{5}{|c|}{---------------- Uncertainty components ----------------} \\
\hline & $\begin{array}{c}\text { Overall limit of } \\
\text { error }^{\text {a }}\end{array}$ & $\begin{array}{l}95 \% \text { L.E. on the } \\
\text { ratio measurements }\end{array}$ & $\begin{array}{l}\text { Possible bias on } \\
\text { determination of } \\
\text { the end point } \\
\text { correction }\end{array}$ & $\begin{array}{l}\text { Possible systematic } \\
\text { error in com- } \\
\text { position of } \\
\text { separated } \\
\text { isotopes }\end{array}$ & $\begin{array}{c}\text { Possible } \\
\text { systematic error } \\
\text { in chemical } \\
\text { analysis }\end{array}$ \\
\hline $\begin{array}{l}\text { Atomic weight }=28.0855258 \\
\text { Nuclidic masses }[12] \\
\quad\left({ }^{12} \mathrm{C}=12\right) \\
{ }^{28} \mathrm{Si}=27.9769286 \\
{ }^{29} \mathrm{Si}=28.9764969 \\
{ }^{30} \mathrm{Si}=29.9737722\end{array}$ & \pm 0.0000555 & \pm 0.0000202 & \pm 0.0000097 & \pm 0.0000073 & \pm 0.0000183 \\
\hline $\begin{array}{l}\text { Atomic percent } \\
{ }^{28} \mathrm{Si}=92.22933 \\
{ }^{29} \mathrm{Si}=4.66982 \\
{ }^{30} \mathrm{Si}=3.10085\end{array}$ & $\begin{array}{l} \pm 0.00383 \\
\pm .00218 \\
\pm .00205\end{array}$ & $\begin{array}{l} \pm 0.00155 \\
\pm 0.00124 \\
\pm 0.00074\end{array}$ & $\begin{array}{l} \pm 0.00063 \\
\pm .00026 \\
\pm .00036\end{array}$ & $\begin{array}{l} \pm 0.00047 \\
\pm .00019 \\
\pm .00027\end{array}$ & $\begin{array}{l} \pm 0.00118 \\
\pm \quad .00049 \\
\pm \quad .00068\end{array}$ \\
\hline $\begin{array}{l}\text { Isotopic ratios } \\
{ }^{28} \mathrm{Si} /{ }^{30} \mathrm{Si} 29.74320 \\
{ }^{29} \mathrm{Si} /{ }^{30} \mathrm{Si} \quad 1.50598\end{array}$ & $\begin{array}{l} \pm 0.02101 \\
\pm \quad .00119\end{array}$ & $\begin{array}{l} \pm 0.00747 \\
\pm .00086\end{array}$ & $\begin{array}{l} \pm 0.00373 \\
\pm .00009\end{array}$ & $\begin{array}{l} \pm 0.00278 \\
\pm .00007\end{array}$ & $\begin{array}{l} \pm 0.00703 \\
\pm \quad .00047\end{array}$ \\
\hline
\end{tabular}

a The overall limit of error is the sum of the 95 percent confidence limits for the ratio determinations and terms covering effects of known sources of possible systematic error.

\section{References}

[1] Shields, W. R., Garner, E. L., and Dibeler, V. H., J. Res. Nat. Bur. Stand. (U.S.) 66A (Phys. and Chem.) 1-3 (Jan.-Feb. 1962).

[2] Shields, W. R., Murphy, T. J., Garner, E. L., and Dibeler, V. H., J. Am. Chem. Soc. 84, 1519-1522 (1962).

[3] Shields, W. R., Murphy, T. J., and Garner, E. L., J. Res. Nat. Bur. Stand. (U.S.) 68A (Phys. and Chem.) 589-592 (Nov.Dec. 1964).

[4] Catanzaro, E. J., Murphy, T. J., Garner, E. L., and Shields, W. R., J. Res. Nat. Bur. Stand. (U.S.) 68A (Phys. and Chem.) 593-599 (Nov. -Dec. 1964)

[5] Shields, W. R., Murphy, T. J., Catanzaro, E. J., and Garner, E. L., J. Res. Nat. Bur. Stand. (U.S.) 70A (Phys. and Chem.) 193-197 (March-April 1966).

[6] Catanzaro, E. J., Murphy, T. J., Garner, E. L., and Shields, W. R., J. Res. Nat. Bur. Stand. (U.S.) 70A (Phys. and Chem.)
453-458 (Nov.-Dec. 1966).

[7] Catanzaro, E. J., Murphy, T. J., Shields, W. R., and Garner, E. L., J. Res. Nat. Bur. Stand. (U.S.) 72A (Phys. and Chem.) 261-267 (May-June 1968).

[8] Catanzaro, E. J., Champion, C. E., Garner, E. L., Marinenko, G., Sappenfield, K. M., and Shields, W. R., Nat. Bur. Stand. (U.S.), Spec. Publ. 260-17, 70 pages (Feb. 1969).

[9] Catanzaro, E. J., Murphy, T. J., Garner, E. L., and Shields, W. R., J. Res. Nat. Bur. Stand. (U.S.) 73A (Phys. and Chem.) 511-516 (Sept.-Oct. 1969).

[10] Gramlich, J. W., Murphy, T. J., Garner, E. L., and Shields, W. R., J. Res. Nat. Bur. Stand. (U.S.) 77A (Phys. and Chem.) 691-698 (Nov.-Dec. 1973).

[11] Garner, E. L., Murphy, T. J., Gramlich, J. W., Paulsen, P. J., and Barnes, I. L., Absolute Isotopic Abundance Ratios and the Atomic Weight of a Reference Sample of Potassium, to be published in J. Res. Nat. Bur. Stand. (U.S.), 79A (Phys. and Chem.) No. 6. (Nov.-Dec. 1975). 
[12] Deslattes, R. D., Henins, A., Bowman, H. A., Schoonover, R. M., Carrol, C. L., Barnes, I. L., Machlan, L. A., Moore, L. J., and Shields, W. R., Phys. Rev. Lett. 33, 463-466 (1974).

[13] Wapstra, A. H., and Gove, N. B., Nuclear Data Tables 9, 265-301 (1971).

[14] Baxter, G. P., Weatherill, P. F., and Scripture, E. W., Jr., Proc. Am. Acad. Arts Sci. 58, 245-268 (1923).

[15] White, J. R., and Cameron, A. E., Phys. Rev. 74, 991-1000 (1948).

[16] Cameron, A. E., and Wichers, E., JACS 84, 4175-4197 (1962).

[17] Atomic Weights of the Elements-1969, Pure Appl. Chem. 21, 93-107 (1970).

[18] Allenby, R. J., Geochim. Cosmochim. Acta 5, 40-48 (1954).

[19] Shields, W. R., (Ed.), Nat. Bur. Stand. (U.S.) Tech. Note 426 , 53 pages (Sept. 1967).
[20] Shields, W. R., (Ed.), Nat. Bur. Stand. (U.S.) Tech. Note 277, p. 8 (July 1966).

[21] Shields, W. R., (Ed.), Nat. Bur. Stand. (U.S.) Tech. Note 277. p. 10 (July 1966).

[22] Shields, W. R., U.S. Patent 2,956,771 (1960).

[23] Reynolds, J. H., and Verhoogen, J., Geochim. Cosmochim. Acta 3, 224-234 (1953).

[24] Smith, R. L., Shields, W. R., and Tabor, C. D., US AEC Report GAT-1711 Rev. 1 (1956).

[25] Rodden, C. J., (Ed.), Selected Measurement Methods for Plutonium and Uranium in the Nuclear Fuel Cycle, 2nd ed. U.S. Atomic Energy Commission (1972).

[26] Tilles, D., J. Geophys. Res. 66, 3003-3013 (1961).

(Paper 79A6-870) 